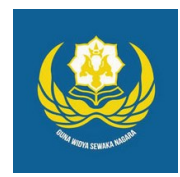

Jurnal Analogi Hukum

Journal Homepage: https://ejournal.warmadewa.ac.id/index.php/analogihukum

\title{
Kekuatan Alat Bukti Akta Otentik Dalam Pembuktian Perkara Perdata
}

\author{
Komang Ayuk Septianingsih*, I Nyoman Putu Budiartha dan Anak Agung Sagung Laksmi Dewi
}

Universitas Warmadewa, Denpasar-Bali, Indonesia

*septianingsih.k.a@gmail.com

How To Cite:

Septianingsih, K, A., Budiartha, I, N, P., Dewi, A, A, S, L. (2020). Kekuatan Alat Bukti Akta Otentik Dalam Pembuktian Perkara Perdata. Jurnal Analogi Hukum. 2 (3). 336-340. Doi: https://doi.org/10.22225/ah.2.3.2584.336-340

\begin{abstract}
Authentic deed is a deed in the form determined by law, made by or in front of the general employees in power for that place where the deed is made, and as for general officials who are authorized to make authentic deeds, namely a Notary or PPAT. The main issue is how the power of authentic deeds is proven in civil cases and how the notary's responsibility for authentic deeds is null and void. The research method used is a type of normative legal research. While the problem approach which is the approach to the conceptual approach problem, is done by examining the views that occur in the development of legal science and the legislative approach, carried out by examining the legal aspects that have a relationship with the legal issues examined. The value of the power of outward proof, the strength of formal proof and the strength of material proof are those covered by an authentic deed. Responsible for negligence and mistakes in the contents of the deed made before him are the responsibility of the notary. In the world of notoriety there are 2 types of sanctions, namely civil sanctions and administrative sanctions. The sanction is imposed on the notary if the deed he has made is an error or a violation of the law, besides that it can also make the deed null and void.
\end{abstract}

Keywords: Letter; Authentic Deed; Proof of Authentic Deed; Notary's Responsibility

\begin{abstract}
Abstrak-Akta otentik ialah suatu akta yang dilterbitkan yang bentuknya telah diatur dalam undang-undang, diterbitkan oleh atau didepan pejabat umum yang berkompeten di bidang itu ditempat atau dimana dibuatnya akta, dan adapun pejabat umum yang berkompeten menerbitkan akta otentik yaitu seorang Notaris maupun PPAT. Pokok permasalahannya yaitu bagaimana kekuatan akta otentik dalam pembuktian pada perkara perdata dan bagaimana tanggung jawab notaris terhadap akta otentik yang batal demi hukum. Metode penelitian yang digunakan ialah tipe penelitian hukum normatif. Sedangkan pendekatan masalah yang adalah pendekatan masalah pendekatan konseptual, dilakukan dengan meneliti pandangan yang terjadi di dalam perkembangan ilmu hukum serta pendekatan perundang-undangan, dilakukan dengan mengkaji dari aspek hukum yang mempunyai hubungan dengan isu hukum yang ditelaah. Nilai kekuatan pembuktian lahiriah, nilai kekuatan pembuktian formal dan nilai kekuatan pembuktian materiil ialah yang di cakup pada akta otentik. Bertanggung jawab apabila terjadi kelalaian dan kesalahan terhadap isi akta yang dibuat dihadapannya merupakan tanggung jawab notaris. Dalam dunia kenotariatan dikenal 2 jenis sanksi, yakni sanksi perdata dan sanksi administratif. Sanksi tersebut dijatuhkan kepada notaris apabila akta itu dibuatnya terdapat kesalahan atau perbuatan melanggar hukum, selain itu pula mampu menjadikan akta itu menjadi batal demi hukum.
\end{abstract}

Kata Kunci: Surat; Akta Otentik; Kekuatan pembuktian Akta Otentik; Tanggung Jawab Notaris

\section{Pendahuluan}

Penyelesaian suatu perkara perdata dalam pengadilan haruslah diperlukan alat-alat bukti yang telah ditemukan maupun telah diakui oleh undang-undang yang berlaku saat ini. Dimana kemudian di muka pengadilan alat-alat bukti tersebut akan dipergunakan untuk dasar dari suatu pembuktian. Dalam Hukum Acara
Perdata dikenal beberapa alat bukti, sebagaimana telah ditentukan dalam Pasal 1866 KUH Perdata yang meliputi, bukti tulisan, bukti dengan saksisaksi, persangkaan - persangkaan, pengakuan, dan sumpah, merupakan penjabaran dari Pasal 1866 Kitab Undang-Undang Hukum Perdata (Tjukup, Layang, Martana3, \& Markeling, 2016). Surat ialah alat bukti tertulis berisi tulisan dalam pernyataan daya pikir 
seseorang yang akan dijadikan sebagai alat bukti (Samudera, 1992). Akta adalah alat bukti tertulis yang diberi tanda tangan serta memuat peristiwa-peristiwa yang menjadi dasar atas perikatan, ataupun selaku landasan dari hak dengan ketetapan sejak awalnya akta ini sengaja diterbitkan untuk menjadi pembuktian (Ali \& Heriani, 2012). Akta sebagai alat bukti tertulis dalam hal-hal tertentu dapat digunakan menjadi suatu alat bukti yang kuat bagi pihak-pihak yang terikat di dalamnya. Salah satu akta yang dibuat sebagai alat bukti yang sah adalah Akta Otentik (Ramadhani, Fakih, \& Febrianto, 2017).

Disebutkan didalam Kitab UndangUndang Hukum Perdata akta otentik ialah suatu akta yang dilterbitkan yang bentuknya telah diatur dalam undang-undang, diterbitkan oleh atau didepan pejabat umum yang berkompeten di bidang itu ditempat atau dimana dibuatnya akta, dan adapun pejabat umum yang berkompeten menerbitkan akta otentik yaitu seorang Notaris maupun PPAT. Dimana Notaris dalam hal ini memiliki suatu kewajiban untuk menelaah apa yang akan dikehendaki para pihak yang bersangkutan ke dalam akta otentik. Akta otentik dikatakan menyandang suatu kekuatan pembuktian yang sempurna, dikatakan demikian karena jika dalam pengajuan ke depan persidangan sebagai alat bukti, akta otentik tidak membutuhkan lagi alat bukti penunjang lainnya untuk membuktikan jika akta otentik itu ialah benar, ini terjadi karena bahwa akta otentik memuat kebenaran-kebenaran fomal yang telah sejalan dengan yang dituangkan para pihak terhadap notaris.

Sesuai dengan pendahuluan yang telah dipaparkan, dapat ditarik rumusan masalahyakni:

Bagaimana kekuatan akta otentik dalam pembuktian pada perkara perdata?

Bagaimana tanggung jawab notaris terhadap akta otentik yang batal demi hukum?

Dan yang menjadi tujuan didalam penelitian ini, adalah:

Untuk mengetahui bagaimana kekuatan akta otentik dalam pembuktian pada perkara perdata.

Untuk mengetahui tanggung jawab notaris terhadap akta otentik yang batal demi hukum.

\section{Metode}

$\begin{array}{ccc}\text { Pada penelitian } & \text { ini, } & \text { penulis } \\ \text { mempergunakan tipe penelitian } & \text { hukum }\end{array}$ normatif. Dimana penelitian hukum tertulis tidak meneliti dari sisi kenyataan ataupun implemetasiyang terjadi di lapangan itulah yang dimaksud dengan penelitian hukum normatif. Pendekatan masalah yang dipakai pada skripi ini adalah pendekatan masalah pendekatan konseptual dan perundang-undangan. Dikatakan pendekatan konseptual karena dilakukan dengan meneliti pandangan maupun suatu doktrin yang terjadi di dalam perkembangan ilmu hukum. Sedangkan pendekatan perundang -undangan dilakukan dengan mengkaji dari aspek hukum perundang-undangan yang mempunyai hubungan terhadap permasalahan yang akan dikaji.

Adapun sumber hukum yang dikaji dalam penelitian ini ialah:

\section{Sumber Bahan Hukum Primer}

Dimana yang dimaksud dengan bahan hukum primer ialah bahan huum yang dapat mengikat peraturan perundang-undangan. Sumber bahan hukum primer pada penelitian ini diproleh dari Undang-Undang Dasar Negara Republik Indonesia Tahun 1945, Kitab Undang -Undang Hukum Perdata dan, Undang-Undang Nomor 30 Tahun 2004 Tentang Jabatan Notaris (UUJN), HIR/RBg.

\section{Sumber Bahan Hukum Sekunder}

Dimana yang dimaksud dengan bahan hukum sekunder ialah bahan hukum yang memaparkan suatu penjabaran terhadap bahan hukum primer yang digunakan, yang mempunyai keterkaitan dengan Akta Otentik.

Adapun teknik pengumpulan bahan hukum yang dilakukan dalam skripsi ini yaitu dengan cara melakukan studi kepustakaan,dimana dilakukan dengan menelaah dari sumber bukubuku maupun literatur. Selain itu, pengumpulan bahan-bahan hukum dilakukan dengan mengkaji peraturan perundang-undangan yang mempunyai keterkaitan dengan pembahasan dalam penelitian ini.

\section{Hasil Penelitian Dan Pembahasan}

\section{Kekuatan Akta Otentik Dalam Pembuktian Pada Perkara Perdata}

Sistem pembuktian Indonesia yaitu menggunakan alat bukti tertulis yang dijadikan sebagai alat bukti yang utama ataupun primer, karena alat bukti tertuli menyandang tingkatan yang utama diantara bukti lainnya sebagaimana dikemukakan oleh undang-undang sementara pengutamaan alat bukti tertulis dikarenakan alat 
bukti tertulis memanglah dijadikan pembuktia (Mulyadi, 1998). Telah disebutkan didalam Kitab Undang-Undang Hukum Perdata akta otentik ialah suatu akta yang di terbitkan yang bentuknya telah diatur dalam undang-undang, diterbitkan oleh atau didepan pejabat umum yang berkompeten di bidang itu ditempat atau dimana dibuatnya akta, dan adapun pejabat umum yang berkompeten menerbitkan akta otentik yaitu seorang Notaris maupun PPAT. Suatu akta otentik memiliki kekuatan pembuktian yang sempurna adalah sempurna dan juga mengikat para pihak yang membuat akta otentik itu sendiri, tetapi jika diajukan ke depn persidangan akta otentik mengikat hakim. Berbeda halnya dengan nilai kekuatan pembuktian dibawah tangan yang hanya mengikat kedua belah pihak yang bersangkutan dan jika di persidangan tidak akan mengikat hakim. Nilai kekuatan pembuktian lahiriah, nilai kekuatan pembuktian formal dan nilai kekuatan pembuktian materiil ialah yang dicakup pada akta otentik. Adapun penjelasaannya yakni:

\section{Nilai Kekuatan Pembuktian Lahiriah}

Nilai kekuatan pembuktian lahiriah dalam akta otentik, dapat terbukti dengan akta itu sendiri dapat dibuktikan sebagai suatu akta otentik. Nilai kekuatan pembuktian akta otentik yang dikaji dari aspek lahiriah,suatu akta otentik tidak perlu diadukan dengan alat bukti lainnya. Dalam hal ini yang bersangkutan dalam pembuatan akta otentik wajib membuktikan bahwa akta tersebut secara lahiriah bukan akta otentik jikalau akta otentik tersebut ada yang menyangkalnya.Suatu penyangkalan bahwa secara lahiriah akta otentik, bukanlah akta otentik, maka haruslah melalui gugatan ke pegadilan. Seorang penggugat haruslah bisa menunjukkan secara lahiriah akta yang dijadikan objek gugatan bukan akta otentik.

\section{Nilai Kekuatan Pembuktian Formal}

Suatu akta otentik patut dapat menunjukkan kepastian terhadap apapun peristiwa maupun kenyataan yang dicantumkan oleh notaris atau diterangkan oleh para pihak sudah sejalan dengan ketentuan atau syarat yang diatur pada penerbitan suatu akta. Dalam pembuktian secara formal dan kebenaran hari, tanggal, bulan, tahun, waktu menghadap, serta para pihak yang menghadap, paraf dan tanda tangan para pihak, saksi maupun notaris, serta membuktikan apa yang dilihat, disaksikan, didengar oleh notaris serta mencatatkan semua pernyataan para pihak. Andikata dari segi formal disengketakan oleh para pihak, maka patut dibuktikan formalitas atas akta itu. Dalam hal ini jikalau ada yang mempermasalahkan kebenaran akta tersebut, maka yang menyangkalnya harus melaui gugatan kemukapersidangan, penggugat patut membuktian bahwa terdapat aspek formal yang dilanngar pada akta tersebut.

\section{Nilai Kekuatan Pembuktian Materiil}

Dalam hal ini segala keterangan maupun pernayataan yang disampaikan kepada notaris yang ada dalam akta tersebut dan dimuat dalam berita acara, haruslah dinilai benar berkata. Dimana lalu akan dimuat kedalam akta tersebut selaku yang benar setiap pihak yang menghadap ke depan notaris. Dan apabila ternyata penyataan-pernyataan tersebut menjadi tidak benar berkata, maka notaris akan tidak terikat dengan hal tersebut, karena itu akan merupakan tanggung jawab dari para pihak yang membuat maupun yang bersangkutan. Dengan demikian daapat dikatakan bahwa isi dari akta otentik menjadipembuktian bagi para pihak maupun para ahli waris dan mempunyai suatu kepastian sebagai yang sebenarnya.

Dari uraian tersebut di atas dapat dikatakan bahwa tiga aspek itulah menjadi suatu kesempurnaan akta notaris selaku akta otentik danjuga pihak yang berhubungan dengan akta tersebut. Andaikata di depan persidangan akta otentik tersebut tidak bisa dibuktikan sebagai akta otentik, maka nilai kekuatan pembuktiannya akan turun menjadi kekuatan pembuktian akta di bawah tangan.

\section{Tanggung Jawab Notaris Terhadap Akta Otentik Yang Batal Demi Hukum}

Oleh Pemerintah dan Undang-undang yang telah berdasarkan atas Keputusan Kementrian Hukum dan HAM, Notaris diangkat menjadi pejabat ummum yang berwenang dalam pembuatan suatu akta.Pada pasal 1 angka 1 Undang-undang Nomor 2 Tahun 2014 tentang Jabatan Notaris telah dijabarkan :

"Notaris adalah pejabat umum yang berwenang untuk membuat akta autentik dan memiliki kewenangan lainnya sebagaimana dimaksud dalam undang-undang ini atau berdasarkan undang-undang lainnya."

Notaris dalam membuat suatu akta haruslah berpedoman pada Undang-undang Jabatan Notaris atau yang biasa disebut dengan UUJN. Dalam membuat suatu akta, Notaris dilarang melakukan suatu perbuatan melawan hukum apalagi yang sampai dapat merugikan orang/ pihak lain. Tolak ukur seorang Notaris 
dalam menjalankan jabatannya ialah tanggung jawab etis yang berkaitan dengan norma moral. Hal ini menjadi tolak ukur notaris dalam mengoreksi benar atau salah tidakan yang dijalankannya.Dengan adanya tindakan melawan hukum yang diperbuat notaris, maka haruslah dipertanggungjawabkan oleh notaris yang bersangkutan.

Peranan notaris bernilai dalam membantu memberikan kepastian hukum ataupun perlindungan hukum terhadap masyarakat mempunyai sifat preventif, yakni sifat mencegah dngan melahirkan akta otentik yang dibuat olehnya yang mempunyai kaitan dengan status hukum, hak maupun kewajiban dalam hukum selaku alat bukti sempurna pada persidangan, andai kata terdapat sengketa (Sjaifurrachman \& Adjie, 2011). Pada Buku III, Bagian Kedelapan, Ban IV yakni dari Pasal 1446 sampai dengan Pasal 1456 Kitab Undangundang Hukum Perdata telah mengatur mengenai kebatalan maupun pembatalan dari suatu akta. Tetapi dalam bagian ini hanya kebatalan khususnya dari kesepakatan yang ditempuh oleh mereka yang tidak cakap, yakni mereka yang dbawah umur, berada di bawah curatele, ataupun cacat dalam kehendak. Adanya desakan, kealpaan, tipu daya, penyalahgunaan keadaan ialah yang dimakud cacat dalam kehendak. Kebatalan dari suatu akta otentik meliputi 3 hal yakni:

\section{Dapat dibatalkan}

\section{Batal demi hukum}

3.Mempunyai kekuatan pembuktian sebagai akta di bawah tangan.

Dujatuhkan status batal demi hukum apabila belum terpenuhinya syarat objektif pada perjanjian. Akta notaris disebut akta otentik jika saat penerbitannya sesuai dengan aturan yang terdaat dalam undang-undang Jabatan Notaris, andaikata akta yang notaris terbitkan terbukti tak sesuai dari aturan maka akta yang notaris terbitkan tersebut tidak akan menyandang kekuatan hukum pembuktian.

Jika suatu akta otentik dinyatakan batal demi hukum maka nilai kekuatan pembuktiannya akan turun menjadi kekuatan pembuktian akta dibawah tangan. Hal ini terbitdikarenakan dari akta tersebut tidak memenuhi syarat-syarat yang sesuai menurut hukum yang berlaku. Terkait dengan hal ini maka status dari akta tersebut akan berifat pasif. Maksud dari kebatalan pasif ialah tanpa adanya tindakan aktif ataupun segala upaya dari para pihak yang bersangkutan dan secara serta merta tidak terpenuhinya semua syarat yang diautur oleh hukum atau undang-undang. Sanksi administrasi pula dapat dijatuhkan terhadap notaris, ada 3 sanksi yani:sanksi reparatif (sanksi ditujukan terhadap tindakan atas pelanggaran tata tertib hukum), sanksi punitif (sanksi sifatnya menghukum selaku beban tambahan), sanksi regresif (sanksi selaku anggapan terhadap tidak patuh atas penarikan hak atas apapun yang diputuskan menurut hukum, seolah-olah kembali kepada keadaan hukum yang tepat sebelum kepatuhan diambil.

Notaris diharuskan agar jujur, adil dan juga transparan saat membuat suatu akta agar terjamin seluruh pihak terkait akta otentik, hal ini dikarenakan seorang notaris mencakup kewenangannya tidaklah semata-mata untuk keperluan perseorangan tetapi juga untuk keperluan masyarakat dan notaris juga memiliki kewajiban dalam menjaminkan keabsahan atas akta yang dibuat olehnya. Selain itu, notaris juga harus berpegang teguh dan tidak melanggar kode etik jabatan notaris. Terkait dalam notaris melaksanakan suatu tindakan yang melawan hukum didasarka pasal 1365 Kitab Undang-undang Hukum Perdata, berbunyi:

"Tiap perbuatan melanggar hukum, yang membawa kerugian kepada orang lain, mewajibkan orang yang karena salahnya menerbitkan kerugian itu, mengganti kerugian tersebut."

Tanggung jawab Notaris ialah menjalankan kewajiban yang meliputi keabsahan materiil akta dibuat olehya, selain itu juga bertanggung jawab apabila terjadi kelpaan serta kekeliruan terhadap isi akta yang dibuat dihadapannya. Sanksi perdata dan sanksi administratif merupakan jenis sanksi yang dikenal didalam dunia kenotariatan. Sanksi tersebut bisa diberikan kepada notaris yang telah terbukti melakukan kesalahan maupun kekeliruan dalam membuat suatu akta otentik. Sedangkan sanksi perdata akan dijatuhkan kepada notaris apabila akta yang dibuatnya terdapat kesalahan yang terjadi akibat wanprestasi atau perbuatan melanggar hukum, dan akibatnya akan menurunkan status kekuatan dari akta otentik yang diterbitkan notaris tersebut hanya selaku mempunyai kekuatan akta dibawah tangan. Serta sanksi lainnya pula dapat menjadikan akta itu menjadi batal demi hukum.

\section{Simpulan}

Telah disebutkan didalam Kitab UndangUndang Hukum Perdata akta otentik merupakan 
suatu akta yang didalam bentuk yang ditentukan oleh undang-undang, dibuat oleh atau dihadapan pegawai-pegawai umum yang berkuasa untuk itu ditempat dimana akta dibuatnya, dan adapun pejabat umum yang berwenang membuat akta otentik yaitu seorang Notaris maupun PPAT. Nilai kekuatan pembuktian lahiriah, nilai kekuatan pembuktian formal dan nilai kekuatan pembuktian materiil ialah yang dicakup oleh suatu akta otentik.

Oleh Pemerintah dan Undang-undang yang telah berdasarkan atas Keputusan Kementrian Hukum dan HAM, Notaris diangkat menjadi pejabat umum yang berwenang dalam pembuatan suatu akta. Notaris dalam membuat suatu akta haruslah berpedoman pada Undang-undang Jabatan Notaris atau yang biasa disebut dengan UUJN. Tanggung jawab Notaris ialah menjalankan kewajiban yang meliputi kebenaran materiil atas akta yang dibuatnya, selain itu juga bertanggung jawab apabila terjadi kelalaian dan kesalahan terhadap isi akta yang dibuat dihadapannya. Jika suatu akta otentik dinyatakan batal demi hukum maka nilai kekuatan pembuktiannya akan turun menjadi kekuatan pembuktian akta dibawah tangan. Hal ini terjadi karena dari akta tersebut tidak memenuhi syarat-syarat yang sesuai menurut hukum yang berlaku.

\section{Daftar Bacaan}

Ali, A., \& Heriani, W. (2012). Asas-Asas Hukum Pembuktian Perdata. Jakarta: Kencana Prenada Media Group.

Mulyadi, L. (1998). Hukum Acara Perdata Menurut Teori dan Praktek Peradilan Indonesia. Jakarta: Djambatan.

Ramadhani, F. Y., Fakih, M., \& Febrianto, D. (2017). Kedudukan Akta Otentik Yang Dibuat Oleh Notaris Pada Pembuatan Akta Jaminan Fidusia. Pactum Law Journal, 1(1). Retrieved from http:// jurnal.fh.unila.ac.id/index.php/plj/ article/download/1040/pdf

Samudera, T. (1992). Hukum Pembuktian dalam Acara Perdata. Bandung: Alumni.

Sjaifurrachman, \& Adjie, H. (2011). Aspek Pertanggungjawaban Notaris Dalam Pembuatan Akta. Bandung: Mandar Maju.
Tjukup, I. K., Layang, I. W. B. S., Martana3, N. A., \& Markeling, I. K. (2016). Akta Notaris (Akta Otentik) Sebagai Alat Bukti Dalam Peristiwa Hukum Perdata. A c Ta $C$ o $\mathrm{m}$ Ita $S$, 2. Retrieved from 24902-1-48968-1-10-20161118.pdf 